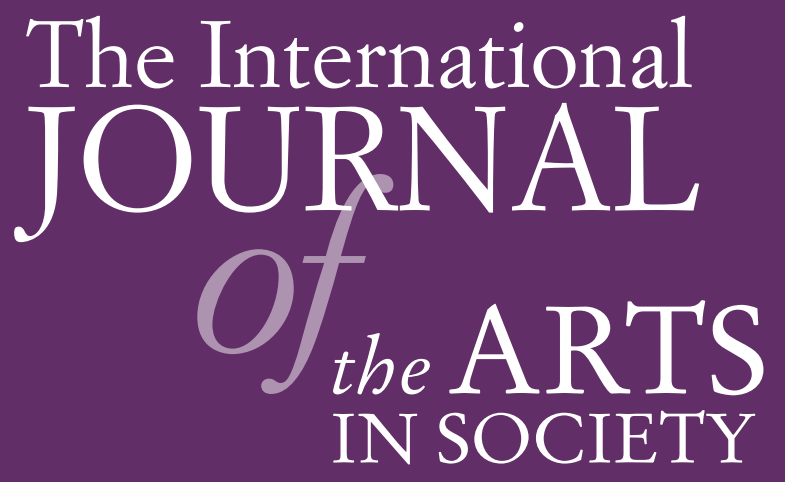

Volume 2, Number 1

The Flower and the Breaking Wheel: Burkean Beauty and Political Kitsch

C. E. Emmer 
THE INTERNATIONAL JOURNAL OF THE ARTS IN SOCIETY http://www.arts-journal.com

First published in 2007 in Melbourne, Australia by Common Ground Publishing Pty Ltd www.CommonGroundPublishing.com.

(C) 2007 (individual papers), the author(s)

(C) 2007 (selection and editorial matter) Common Ground

Authors are responsible for the accuracy of citations, quotations, diagrams, tables and maps.

All rights reserved. Apart from fair use for the purposes of study, research, criticism or review as permitted under the Copyright Act (Australia), no part of this work may be reproduced without written permission from the publisher. For permissions and other inquiries, please contact <cg-support@commongroundpublishing.com>.

ISSN: 1833-1866

Publisher Site: http://www.Arts-Journal.com

THE INTERNATIONAL JOURNAL OF THE ARTS IN SOCIETY is a peer refereed journal. Full papers submitted for publication are refereed by Associate Editors through anonymous referee processes.

Typeset in Common Ground Markup Language using CGCreator multichannel typesetting system http://www.CommonGroundSoftware.com. 


\title{
The Flower and the Breaking Wheel: Burkean Beauty and Political Kitsch
}

\author{
C. E. Emmer, Emporia State University, Kansas, USA
}

Abstract: What is kitsch? The varieties of phenomena which can fall under the name are bewildering. Here, I focus on what has been called "traditional kitsch," and argue that it often turns on the emotional effect specifically captured by Edmund Burke's concept of "beauty" from his 1757 'A Philosophical Enquiry into the Sublime and Beautiful.' Burkean beauty also serves to distinguish "traditional kitsch" from other phenomena also often called "kitsch"-namely, entertainment. Although I argue that Burkean beauty in domestic decoration allows for us to see "traditional kitsch" as resting on natural and even healthy impulses, I also argue that an all-too-common political function of traditional kitsch directs it to dangerous ends.

Keywords: Beauty, Burke, Camp, Cute, Comfort, Danger, Decoration, Domestic, Home, Ideology, Irony, Kitsch, Political, Power, Propaganda, Safety, Security, Sublime, Traditional Kitsch

\section{Beauty Reconsidered ${ }^{1}$}

$\mathrm{T}$

HE LAST FEW years have witnessed a number of reconsiderations of the place of beauty in relation to art. One of the most prominent is the recent book, The Abuse of Beauty, by philosopher and art critic Arthur C. Danto. ${ }^{2}$ Danto's main early work had provided the tools to later show that, though eighteenth- and nineteenth-century thinkers had seen beauty to be an essential element of an artwork, beauty in fact has no necessary relation to whether something qualifies as an artwork. ${ }^{3}$ This independence of art from beauty, however, has now freed him to recuperate in The Abuse of Beauty a certain legitimate place for beauty in art without the burden of assuming that beauty was art's sine qua non.

I plan to do something similar here: to cautiously rejuvenate a particular idea of beauty, this time in relation to kitsch. Namely, Edmund Burke's eighteenth-century conception of beauty (from A Philosophical Enquiry into the Origin of Our Ideas of the Sublime and Beautiful) ${ }^{4}$ will allow me to clarify a subset of kitsch which has been called "traditional kitsch." $"$ Burkean beauty will allow me to distinguish this "traditional kitsch" from entertainment and it will also allow me mount a limited defense of "traditional kitsch." At the same time, however, I will ultimately qualify this defense of kitsch with a strong caveat - also informed by Burke's aesthetic categories - about the dangers that "traditional kitsch" almost unavoidably invites when, serving political ends, it is transformed into political kitsch.

\section{Back to Traditional Kitsch}

As soon as one opens a discussion of kitsch, the incredible variety of phenomena which have been la-

\footnotetext{
${ }^{1}$ This article grew out of a paper I presented at the Symposium on the Arts in Society at New York University (NYC) February $23-25$ 2007. I thank all who attended for their helpful questions and remarks. In particular, I wish to thank my friend, James DiGiovanna (instructor of philosophy in the Master's program at Stony Brook Manhattan, NYC), who has led me to reconsider important aspects of my initial conceptions of kitsch and who has made many helpful suggestions. Of course, any misconceptions to which I am still subject should not be attributed to him, nor to those who commented on my paper. Under a similar proviso, I extend my thanks to Professor Monica Kjellman-Chapin, who made me more familiar with the Thomas Kinkade phenomenon, and to Professor Deborah Gerish of Emporia State University (Emporia, KS) for her great help in making my text more intelligible. Finally, I must extend my thanks to an anonymous reviewer who gave pointed criticisms to many parts of this essay and helped me make it clearer.

2 Arthur C. Danto, The Abuse of Beauty: Aesthetics and the Concept of Art, The Paul Carus Lectures 21, (Chicago: Open Court, 2003). Also arguing for a more contextually aware - and thus more nuanced - approach to beauty is Llewellyn Negrin, "The Contradictory Nature of our Relation to Beauty in Contemporary Culture," The International Journal of The Arts in Society 1:3 (2007): 135-140.

${ }^{3}$ Arthur C. Danto, The Transfiguration of the Commonplace: A Philosophy of Art (Cambridge: Harvard University Press, 1981). In this book he had already stated that, as far as beauty and art were concerned, "Making beautiful things is of course an exalted activity, as beauty is an exalted quality; but aesthetics, as we have so often seen, hardly touches the heart of art and certainly not of great art, which is certainly not the art that happens to be the most beautiful" (p. 173).

${ }^{4}$ Edmund Burke, A Philosophical Enquiry Into the Sublime and the Beautiful [1757/1759], (New York: Penguin Books, 1998/2004). Burke's own divisions will be used instead of page numbers.

5 Aleksa Ĉelebonović thematized the term "traditional kitsch" in his essay, "Notes on Traditional Kitsch," in Gillo Dorfles, Kitsch: The World of Bad Taste (New York: Bell Publishing, 1969), pp. 280-289. My usage here, at least as far as the referent is concerned, bears comparison to Ĉelebonović's.
}

THE INTERNATIONAL JOURNAL OF THE ARTS IN SOCIETY, VOLUME 2, NUMBER 1, 2007

http://www arts-journal com, ISSN 1833-1866

(C) Common Ground, C. E. Emmer, All Rights Reserved, Permissions: cg-support@commongroundpublishing.com 
belled as kitsch forces us to answer the question, What is meant by kitsch in the first place? ${ }^{6}$

In its loosest-and, I would contend, least useful-sense, it is simply synonymous with whatsoever one considers to be made or consumed in "bad taste." This wider sense, however, has grown from an older, core meaning: the schmaltzy and sometimes tacky bric-a-brac that accumulates in displays on kitchen shelves, on top of parents' and grandparents' dressers, on living room walls and on top of living room television sets, in the nooks and crannies of gardens, and even on and around office computers. These are the $U r$-kitsch phenomena to which the word always seems ready to return, and which for that very reason have been called "traditional kitsch." The etymology or history of the word is foggy at best, but the heritage of this core meaning can be felt in this etymological foray from Gillo Dorfles' introduction to his cornerstone anthology on kitsch:

The word kitsch could derive etymologically from the English 'sketch' or, according to other opinions, from the German verb verkitschen (to make cheap). According to Giesz (Ludwig Giesz: Phänomenologie des Kitsches [Rothe, Heidelberg, 1960] which is without doubt the most complete on the subject), the word kitsch could approximately be said to mean 'artistic rubbish.7

In his anthology on kitsch, Dorfles and his collected authors utilize Hermann Broch's concept of a Kitschmensch (the kitsch-person or kitsch attitude) to greatly expand upon this core meaning of "traditional kitsch" to include cinema, automobile design, modern architecture, shopping malls, and tourist resorts. When, in his anthology, Dorfles finally introduces the essay on "traditional kitsch," the last essay in the book, he almost has to apologize for having put off for so long what is, after all, the very homeland - or Heimat - of kitsch:
There is a traditional - or rather, a so-called traditional-type of kitsch that has virtually become a commonplace. All the writings and publications which have been concerned with the problem of bad taste usually dwell on this type, which - though this must be said with the utmost caution - is probably less dangerous than the other more insidious forms we have examined so far. [...W] have preferred to put it at the end of a book so as to show that it is relatively unimportant and in a certain sense inoffensive. ${ }^{8}$

As can be seen from Dorfles' remarks, "traditional kitsch" is what one usually encountered in books on kitsch, ${ }^{9}$ and what Dorfles saw as the signal advantage of his anthology was that he had brought minds to the topic which could push the concept into until then relatively unexplored-i.e., less "traditional"-realms of kitsch. Even though it was commendable to search for untrodden paths, I am afraid that something might have gotten lost in the all the pathbreaking.

What got lost, then? It is my belief that many things which have fallen under the rubric of kitsch would be better understood if seen instead as a form of entertainment. This holds particularly in the Dorfles anthology (which self-consciously expands upon traditional kitsch) but also in various other kitsch compendia. In more intellectual contexts generally, kitsch is practically interchangeable with popular culture. My contention here is that, within popular culture (or "kitsch" in its looser sense), there is a basic difference between two types of phenomena. And I will argue here that Burke's conception of beauty can help us quickly arrive at the heart of that difference. To be more concrete, the sorts of objects which Burkean beauty should be able to unite would include paintings of large-eyed crying children; snow-globes of cheery or peaceful winter scenes; pseudo-impressionist landscapes which show warm scenes of cozy cottages nestled amongst colorful flower bushes or glowing snowdrifts; billboards for

\footnotetext{
${ }^{6}$ An attempt at a taxonomy of critical treatments of "kitsch" phenomena can be found in C. E. Emmer, "Kitsch Against Modernity," Art Criticism 13:1 (1998): 53-80. The present piece liberally draws from, but also revises, that earlier treatment.

7 Dorfles, Kitsch: The World of Bad Taste, p. 10 (punctuation slightly amended). In his anthology's title article, "Kitsch,” Dorfles goes on to say that "Even the word kitsch, once used only in Germany (probably because the problem was particularly acute there), has now spread and is used in the Anglo-Saxon countries as well as in Italy" (p. 15). On a somewhat anecdotal plane, I would have to say that the greatest preponderance of books on kitsch (at least books with the word "kitsch" in their titles) does appear to be in the German language.

${ }^{8}$ Dorfles, Kitsch: The World of Bad Taste, p. 279.

${ }^{9}$ See e.g., Curtis Brown, Star-Spangled Kitsch: An Astounding and Tastelessly Illustrated Exploration of the Bawdy, Gaudy, Shoddy MassArt Culture in This Great Land of Ours (New York: Universe Books, 1975). For a more recent example, see Peter Ward, Kitsch in Sync: A Consumer's Guide to Bad Taste (London: Plexus, 1991), which also devotes much space to cinema and fashion, as well as artists' and filmmakers' recycling of popular culture in the "camp" mode. Many of such books float between disdain and celebration. The even more recent collection, Wayne Hemingway, Just Above the Mantelpiece: Mass-Market Masterpieces (London: Booth-Clibborn Editions, Ltd., 2000), however, explicitly states, "I have seen [mass-market art] celebrated in a post-modernist ironic way and I have been saddened by its inclusion in kitsch iconography. Let's not celebrate it for these reasons. Value deserves to be restored to a genre derided by certain members of the art elite and respect should be given to the artists whose work broadened the horizons of collecting to reach the working classes, making this art form available to a wider public than ever before" (pp. 4-5).
} 
Christian summer camps showing a benevolent Caucasian Christ assisting a child with his paper airplane; Norman Rockwell magazine illustrations; and the typical tchotchkes sold in the many "Grandma's craft-basket"-type gift shops found along highways in conjunction with "family dining." My contention is that there is something that holds most of these together as a group. ${ }^{10}$

But even if one ultimately does not believe that what is more "essential" to kitsch is the phenomenon of traditional kitsch, or even that kitsch is the proper term for the phenomena in question, what I hope will have to be conceded (if my following argument convinces) is that the phenomena here being calling traditional kitsch and what we could label entertainment are at base two different phenomena, which therefore should be distinguished from one another. Without this basic distinction in play, one finds traditional kitsch items (such as those I've just listed) bound together with the most divergent types of things - violent video games, mass-produced reproductions of Leonardo and Picasso alike, intellectual articles from the New Yorker magazine, automotive tail fins, country music as well as heavy metal, and summer tourist spots replete with belly-dancing, water-skiing, and roller coasters.

Before going any further, I should make one thing clear about what I have in mind when I speak of kitsch. At base, I will be treating kitsch as an emotional — or at least, subjective - phenomenon. By this I mean that one and the same object could be kitsch in one context but not kitsch in another. I will be using the word kitsch and its correlates to refer to a single-order intention or attitude toward the product in question: a simple enjoyment of the "kitsch" object because its "kitschy" aspects are enjoyed as directly good. As a consequence, if the same object were enjoyed for the fact that its "kitschy" aspects were understood to be in bad taste (precisely because they were understood to be inferior), we would then not be faced with kitsch, but rather camp, irony, or some similar attitude which rests on a feeling or posture of knowing superiority to the product in question. ${ }^{11}$ Someone, therefore, who has purchased an angel figurine from a rummage sale or from an on-line "collectibles" shop and who enjoys looking at it for the very reason that they find it to be tacky or tasteless or atrocious does not exemplify the phenomenon of kitsch, but rather of camp. Why does this mere change in attitude make such a difference? In such a case, the object no longer serves the same function it did as kitsch. ${ }^{12}$

Having made that clarification, however, we are met immediately with another serious problem, one which rests on the fact that the term kitsch itself is generally understood to be derogatory. So, unless the word is meant ironically (and in that case, we would be discussing camp, or arch hip, etc.), it appears the word in the sense I am using can only be applied from the "outside," since (given the word's usual derogatory sense) a person directly enjoying kitsch would not call it kitsch, but rather beautiful, wonderful, charming, sweet, nice, or some similar approbative term. Generally speaking, the term "kitsch" is used to show disapproval of someone else's approval or disapproval of the possibility that something could merit approval. For the most part in this piece, however, I shall not be devoting time to discussing the artistic or aesthetic merits or demerits of the "kitsch" items in question. Instead I shall devote my time to revealing the basic functions that these objects are meant to fulfill, and to the question of whether those functions help us or harm us. Finally, given that, in the following I will be using a certain sense of beauty - namely, Edmund Burke's concept of beauty - to clarify the heart of traditional kitsch, I will often speak of Burkean beauty instead of using the term traditional kitsch. ${ }^{13}$

\section{Burkean Beauty}

The concept of "beauty" can be applied with as much variety as that of "kitsch"-not merely in everyday contexts, but in more academic treatments, as well.

\footnotetext{
${ }^{10}$ I don't ultimately believe that a definition can be provided which would capture all of traditional kitsch-the particular stories and personal idiosyncrasies which help select what ends up on kitchen shelves and on top of televisions would make such a definition impossible. Nonetheless, as I shall presently explain in more detail, I do believe that many of them serve a common function.

${ }^{11}$ Dorfles refers to "the use by a culturally sophisticated public, of elements which are decidedly kitsch (furniture, furnishings and pictures of course, statues, etc.) but which are redeemed by the particular attitude that likes to be called 'camp,' itself, in a way, a rival to kitsch", and goes on to quote Susan Sontag's remark that "Many examples of camp from a 'serious' viewpoint are bad art or kitsch. Not all, however. Not only is camp not necessarily bad art; there are even works of art which can be considered camp ... and even deserve the most serious admiration." Kitsch: The World of Bad Taste, p. 291-292, citing Susan Sontag, "Notes on Camp," in Against Interpretation: And Other Essays, (New York: Picador/Farrar, Strauss and Giroux, 2001), p. 278 (citation amended). I certainly have no illusions that, with only this short mention, the concept of "camp" (or indeed, Sontag's particular concept) has been done justice; the point is simply that the "kitsch" phenomena I have in mind do not involve the sort of indirect, inverting, self-consciously referential structure encountered in camp and irony.

12 To cite a more mundane but analogous opposition, someone who penetrates the stomach of another with a scalpel in order to perform life-saving surgery is not carrying out the same act as someone who penetrates the stomach of another with a scalpel in order to murder them, even though both undeniably plunge a scalpel into another's stomach.

${ }^{13}$ I would hope to be able to say, with Burke, "I am in little pain whether any body choses to follow the name I give [...] or not, provided he allows that what I dispose under different heads are in reality different things in nature. The use I make of the words may be blamed as too confined or too extended; my meaning cannot well be misunderstood." Philosophical Enquiry, preface to the first edition.
} 
In the context of discussing kitsch, however, I believe that Edmund Burke's treatment of beauty can assist us in two ways. The first goes to Burke's general distinction between the beautiful and the sublime. In his Philosophical Enquiry, Burke wrote that he

observed that the ideas of the sublime and the beautiful were frequently confounded; and that both were indiscriminately applied to things greatly differing, and sometimes of natures directly opposite. Even Longinus, in his incomparable discourse upon a part of this subject, has comprehended things extremely repugnant to each other, under the common name of the Sublime. The abuse of the word Beauty, has been still more general, and attended with still worse consequences. ${ }^{14}$

The same could be said of the term "kitsch": the variety of phenomena that fall under the term is so great that even phenomena of essentially opposed natures are found collected together, nestled next to each other in the same conceptual "kitsch" display cabinet.

The second way that Burke's treatment of beauty can clarify kitsch relates to the first. For Burke's particular conception of beauty will help to expose a most basic divide among supposedly similar "kitsch" phenomena. How does Burke conceive of beauty, then? Focusing on our bodily or animal aspect, he divides the "ideas capable of making a powerful impression on the mind" into two basic types, those relevant to self-preservation and those relevant to society. ${ }^{15}$ The root of self-preservation, turning on alterations of pain in "modifications" (or a "mode") of terror, delivers the feeling of the $s u b$ lime, whereas the root of social connection, pleasure, delivers the feeling of the beautiful. More specifically, Burke writes that beauty is

a social quality; for where women and men, and not only they, but when other animals give us a sense of joy and pleasure in beholding them, (and there are many that do so) they inspire us with sentiments of tenderness and affection towards their persons; we like to have them near us, and we enter willingly into a kind of relation with them. ${ }^{16}$
Though he does say that beautiful objects-by definition - inspire the passion of love, and though he does recognize a natural urge which drives humans (and other animals) to procreate, the two should not be confused. He distinguishes love from mere lust (or, as he also calls it, desire):

We shall have a strong desire for a woman of no remarkable beauty; whilst the greatest beauty in men, or in other animals, though it causes love, yet excites nothing at all of desire. Which shews that beauty, and the passion caused by beauty, which I call love, is different from desire... 17

Turning to the emotional or bodily influence in question, Burke explains that, in being affected by a beautiful object,

the mouth is a little opened, and the breath drawn slowly, with now and then a sigh: the whole body is composed, and the hands fall idly to the sides. All this is accompanied with an inward sense of melting and languor. [...] Who is a stranger to that manner of expression so common in all times and in all countries, of being softened, relaxed, enervated, dissolved, melted away by pleasure?",18

Without being burdened by Burke's specific physiological explanations of this process, or the specific physical qualities he takes to be characteristic of beautiful objects, we may focus on the type of attitude he describes: a sense of release, relaxation, comfort, and sweetness - this is emotional core of Burkean beauty. Ultimately, Burke takes these feelings to foster a healthy, mutually supportive relationship with one's society and fellows.

The precise type of beauty in question here should not be overlooked: Burke's idea of "beauty" is actually much closer to what we today would just as often call "pretty" or "cute" (Burke himself discusses beauty in terms of "sweetness," "tenderness," and "affection") - something that evokes some type of calm, reassuring relaxation and repose. ${ }^{19}$ As Danto remarks, in words that strikingly parallel Burke's discussion of beauty, "Cuteness in a work of art, exactly as in life, is a way of getting us to feel warm and protective toward what is seen to possess it." 20

\footnotetext{
${ }_{14}$ Philosophical Enquiry, preface to the first edition.

${ }^{15}$ Philosophical Enquiry, Part I, Sect. VI and passim.

${ }^{16}$ Philosophical Enquiry, Part I, Sect. X.

${ }_{17}$ Philosophical Enquiry, Part III, Sect. I.

${ }^{18}$ Philosophical Enquiry, Part IV, Sect. XIX.

19 The "prettiness" - or "cuteness" — of Burkean beauty first hit me as I was leafing through Hartwig Schmidt's essay, "Hübschheit und Schönheit," on the difference between the "beautiful" and the "pretty"; the basic distinction in his essay pushed me to think more clearly about the specific type of beauty which Burke had in mind. "Hübschheit und Schönheit: Zur Ästhetik leibhaftiger Individualität," in his collection Grausamkeit und andere Lüste: Ethische Essays (Berlin: Berliner Debatte Wissenschaftsverlag, 1998), pp. 18-43.

${ }^{20}$ Danto, The Abuse of Beauty, p. 59.
} 
Upon reflection, it can be seen that the feelings at issue in Burkean beauty are the feelings at the heart of traditional kitsch. They are what the examples of traditional kitsch we saw earlier are about: repose, melting release, healing and retreat, comfort, sweetness, kindness, sanctuary. Danto speaks of artistic beauty as part of the creation of a Garden of Eden which "put[s] the harshness of world at a distance" and, in a higher mode, as a means of "put[ting] suffering in a philosophical perspective." 21 And these feelings or these aims serve to distinguish what is here being referred to as "traditional kitsch" from many of the other phenomena also called kitsch, but which might be better referred to as types of entertainment: amusement park rides, video games, performances by the glam-rock band KISS, science fiction action movies, etc. These are about excitement, thrill-seeking, and high energy diversion - phenomena in some ways much more akin to Burke's idea of the sublime - and not repose. Granted, these two classes, that of "traditional kitsch" (Burkean beauty) and that of entertainment (something more akin to Burke's sublime) do not exhaust the incredible abundance of phenomena labelled as "kitsch," but with these two classes, one has a grasp of a central divide. $^{22}$

As we have seen, for Burke the feelings connected to the beautiful are social. These are healthy feelings necessary to the preservation and maintenance of society and furthermore necessary to the establishment of a good life amongst our fellow living beings. ${ }^{23}$ Here it might be noted that both Burke's idea of the sublime and the beautiful imply a certain power differential. ${ }^{24}$ The Burkean sublime involves moderated terror, a relation to something which generates feelings connected to things or forces more powerful than oneself, something which could threaten one's safety or life itself, should it come to that. It is not actual panic, but a fear which is in one way or another tempered - the feeling of the sublime is a type of what Burke calls delight, a sort of relief (though not a positive pleasure) at the lessening of, or at having a perceptible distance from, pain or danger. $^{25}$

What is perhaps not so often underscored is the fact that Burkean beauty also involves at least an implied power differential: generally, that which is beautiful in Burke's conception is something which one wants to bring closer so that one may protect and care for it. And this is part of its health, I would argue: a healthy society is one which cares for those in need, those who, for whatever reason, may require our assistance and protection. ${ }^{26}$ When a home is provided with Burkean beauty, it serves to create a space of retreat, comfort, stasis, and sanctuary. (And the domestic sphere is, as we have seen, the natural locus of traditional kitsch.) It seems to follow that Burkean beauty (or traditional kitsch) arguably plays

\footnotetext{
${ }^{21}$ Danto, The Abuse of Beauty, p. 115.

22 This divide between two basic classes, based on a divide between two basic types of function, also does not rule out the possibility that some products might combine these functions, particularly temporally structured ones, such as music, narrative, theater, or film (examples might be anime or the Ewoks of the Star Wars series). Given that Burke argues that a person can simultaneously experience pleasure and pain, it is not surprising that he also admits that some product might combine both the beautiful and the sublime, though the combination would be difficult to pull off effectively, and would not prove that the beautiful and the sublime were the same thing. Philosophical Enquiry, Part III, Sects. XIII and XXVII.

${ }^{23}$ Burke notes that the passions "of society ... may be divided into two sorts. I. The society of the sexes, which answers to the purposes of propagation; and next, that more general society, which we have with men and with other animals." Philosophical Enquiry, Part I, Sect. VIII. In a certain sense Burke could be read as ascribing to providence a kind of overflowing generosity; Burke certainly sees these social connections as serving human ends. But, as he notes, it carries us even into kind relations to some of our fellow (non-human) animals.

${ }^{24}$ The presence of this power differential in Burke's theory receives treatment in Steven Cresap, "Sublime Politics: On the Uses of an Aesthetics of Terror," Clio 19:2 (Winter 1990): 111-125. Cresap also notes the all-but-explicit gender identification (men lend themselves to sublimity, women to beauty) in Burke's text (pp. 120-121); see e.g., Burke, Philosophical Enquiry, Part III, Sect. IX. The corresponding trope in Immanuel Kant's 1764 Observations on the Feeling of the Beautiful and the Sublime as well as in contemporary discussions of kitsch is discussed briefly in Emmer, "Kitsch against Modernity," p. 58.

${ }^{25}$ Philosophical Enquiry, Part I, Sect. IV.

${ }^{26}$ One could compare Karl Marx the "humanist" here, who observes that a society can be judged by how it treats those who have been assigned a subservient position:
}

In the relationship to woman, as the plunder and handmaid of communal lust, is made explicit the infinite degradation in which the human being exists for itself, for the secret of this relationship has its unambiguous, decisive, revealed, exposed expression in the relationship between man and woman and in the way that the immediate, natural species relationship is seized. The immediate, natural, necessary relationship between human being and human being is the relationship of man to woman. ... From this relationship one can thus judge the entire level of development of human being.

Karl Marx, Ökonomisch-philosophische Manuskripte, "Privateigentum und Kommunismus" [Economic and Philosophic Manuscripts of 1844, "Private Property and Communism"] No. 1 (my translation). In Marx and Engels, Werke, Ergänzungsband, 1. Teil, S.465-588, Dietz Verlag, Berlin (DDR), 1968, p. 535 (online transcription of German text by Einde O'Callaghan for <www.marxists.org>). Philosopher John Rawls's idea of a "veil of ignorance," resting not on a Marxian foundation, but rather a Kantian one, leads to strikingly similar conclusions regarding the treatment of those in a subservient role. See the Rawls section of Stuart White's "Social Minimum," in the Stanford Encyclopedia of Philosophy (Winter 2004 edition). 
a part in meeting a basic, human need for a healthy domestic space, ${ }^{27}$ one which not only provides comfort and security, but does so in part through fostering feelings of sympathy, compassion, and kindness in the dweller. And, ideally, one's domestic rejuvenation of these emotional capacities allows one to care for others.

\section{Ambivalent Kitsch: Bob Ross vs. Thomas Kinkade}

Kitsch is not always so comforting. Indeed, some kitschographers have attacked kitsch as purely, diabolically vile. The moral theologian Richard Egenter, for example, saw Christian kitsch as an instrument of Satan, ${ }^{28}$ whereas the literary theorist Hermann Broch characterized the maker of kitsch as "an ethically depraved person, a criminal who desires the radically evil." ${ }^{29}$ Kitsch, as has just been argued, can be defended against such extreme reactions. But the tides have turned, it seems, for kitsch. Many of the more recent discussions of kitsch and popular culture generally (especially in the 1980s and 1990s) are unselfconsciously celebratory - they call for gleeful consumption. That celebratory extreme, too, has come to be questioned. ${ }^{30}$ The following discussion will place this essay within those approaches that find in kitsch both needed balm and lurking danger.

Kitsch is an inherently ambivalent phenomenon. From early on, I have noted in myself the conflicting attitudes of dismissiveness as well as uncritical im- mersion, and, in my earlier work, I made a case for kitsch's place in the home as part of a natural and healthy defense mechanism (not unlike the case I have just made with the assistance of Burke). I focused then on the do-it-yourself landscape paintings of Bob Ross's television program, The Joy of Painting $^{\mathrm{TM}}$, because both his paintings and his television show lend themselves so well to the creation of domestic sanctuary and because (as David Halle has shown) landscapes play a central role in actual domestic sanctuaries. In the interim, however, I came to realize that, even though both Bob Ross and Thomas Kinkade paint "traditional kitsch" landscapes, those landscapes are not the same. ${ }^{31}$ And the difference between them is important-important enough that we should spend some time looking into their respective works in more detail. We shall ultimately be rewarded for this by a deeper understanding of the different functions that traditional kitsch can carry out.

For many years, Bob Ross (1942-1995) appeared on PBS stations across the United States to host his show, The Joy of Painting (selected episodes are still being broadcast on many PBS stations under the title, The Best of the Joy of Painting ${ }^{\mathrm{TM}}$ ). His company, Bob Ross Inc., offers painting supplies, classes with certified instructors, and instructional materials such as books and DVDs. ${ }^{32}$ In the half-hour broadcasts of his do-it-yourself series, he starts with an empty canvas and ends with a completed painting, often depicting a mountain lake surrounded by trees. While he paints, he explains to the viewer how to make

\footnotetext{
${ }^{27}$ Here there is significant overlap with Emmer, "Kitsch against Modernity," which however focused not merely on kitsch's ability to provide a perceived connection to stasis and sanctuary, but also to tradition and nature. I should add (drawing again from "Kitsch against Modernity") that the status of the home as a locus of retreat and sanctuary for the dweller has been empirically verified by David Halle's Inside Culture, and that the connected universal preference for landscapes he documented (independently confirmed by Komar and Melamid) has recently been re-confirmed by Halle in studies he and Elisabeth Tiso are carrying out in New York City art galleries in the Chelsea district of Manhattan, NYC. David Halle, Inside Culture: Art and Class in the American Home (Chicago: University of Chicago Press, 1986) and David Halle and Elisabeth Tiso, "The Structure of Contemporary Art: The Case of Chelsea in New York City," paper presented at the International Symposium on the Arts in Society (February 23-25, 2007 at the Tisch School of the Arts at New York University, NYC).

${ }^{28}$ Richard Egenter, The Desecration of Christ, ed. Nicolete Gray, trans. Edward Quinn (Chicago: Franciscan Herald Press, 1967).

${ }^{29}$ Hermann Broch, Schriften zur Literatur 2: Theorie, ed. Paul Michael Lützeler (Frankfurt am Main: Suhrkamp Verlag, 1975) p. 95 (my translation). Selections from Broch's writing on kitsch are translated into English in Gillo Dorfles, Kitsch: The World of Bad Taste.

${ }^{30}$ An interesting treatment of some of these issues is Jonathan E. Schroeder, "Aesthetics Awry: The Painter of Light and the Commodification of Artistic Values," Consumption, Markets and Culture 9:2 (June 2006): 87-99. Schroeder contends that traditional aesthetic categories have blinded experts in marketing, of all people, to the crass operation of marketing on the part of Thomas Kinkade. On the other hand, his argument also avoids the mistaken notion that marketing is inoperative in "high art" contexts. For more on market forces and commercialism in the British art world, see Julian Stallabrass, High Art Lite: British Art in the 1990s (Verso Books, 1999). Schroeder cites Stallabrass, Art Incorporated: The Story of Contemporary Art. (Oxford: Oxford University Press, 2004). Of course an American locus classicus for questions of art and commercialism is Clement Greenberg's 1939 essay, "Avant-Garde and Kitsch," reproduced in part in Dorfles, Kitsch: The World of Bad Taste. Clement Greenberg, "Avant-Garde and Kitsch,” in Art and Culture: Critical Essays (Boston: Beacon Press, 1961), pp. 3-21 (Dorfles, pp. 116-126 = parts III-IV of Greenberg's essay). Stallabrass could be seen as carrying forward Greenberg's concern with the artist's attachment to the elite through "an umbilical cord of gold."

${ }^{31}$ It was especially Susan Orlean's account of Thomas Kinkade's landscape paintings that re-awoke me from my kitschy slumber: Susan Orlean, "Art for Everybody: Thomas Kinkade, America's Most Profitable Artist," The New Yorker (October 15, 2001): 124-146.

${ }^{32}$ Images of Bob Ross's paintings, as well as numerous products and further information, can be found online at $<$ www.bobross.com $>$. A precursor to Bob Ross was William ("Bill”) Alexander (1915-1997), another television painter, whose own show was The Art of William Alexander (also The Magic of Oil Painting), and who developed some of the painting techniques used by Bob Ross. The Alexander Art Corporation also offers classes ("Alexander Seminars") with certified instructors. See $<$ www.alexanderart.com $>$ online for more information and images of paintings. Robert Warren is another television painter descended from Alexander. Images of his work, products, and classes can be found online at <www.robertwarrenartloft.com $>$. All three artists have had or do have painting shows on PBS. More recently (as of October, 2006, on PBS member station WCEU-Channel 15 in Daytona Beach), Morris Wiener has also started a Bob Ross-inspired PBS
} 
their own version of the painting he is making, all the while speaking in a warm, soothing voice. As one of his signature contributions, he refers to the trees, rocks, clouds, and other features he paints as "happy little trees" or a mountain which "lives right here," giving all parts of the painting (and the painting process) a non-threatening, comforting atmosphere. ${ }^{33}$ He reassures the viewer that, if they are trying to make a painting, too, they should not worry - mistakes usually work right into the painting as "happy accidents." Simply seen as a television show - that is, even for the viewer who has no intention of ever purchasing painting supplies and trying their hand at painting - The Joy of Painting has a very reassuring, calming, even therapeutic effect. ${ }^{34}$ Now let us turn to Thomas Kinkade, who at first sight might seem to be making products essentially the same as Bob Ross's. As we shall see presently, Kinkade's output has an importantly different character.

Thomas Kinkade, the "painter, best-selling author, inspirational speaker, CEO, real estate developer",35 and self-proclaimed Painter of Light ${ }^{\mathrm{TM}}$, is famous for his paintings of cozy cottages, glowing with his trademark light effect. Unlike Bob Ross, Kinkade is not seen as a television advocate of do-it-yourself painting: consumers of his work purchase expensive reproductions of his paintings which mimic the texture of a painting. ${ }^{36}$ These reproductions are distributed through his chain of Thomas Kinkade Signature Galleries, located in shopping malls across North America and Europe. ${ }^{37}$ The paintings can also be given special airbrushed accents by specially trained "highlighters" who make appearances at his galleries during a "Master Highlighter Event.",38 Kinkade's paintings often represent his well-known cottages but also depict other scenes, such as lighthouses, bridges, or even American flags such as those in his
"Flags Over America" series. One, America's Pride, shows an American flag in front of the White House; another, Light of Freedom, an American flag in front of a New York City skyline. ${ }^{39}$ Kinkade's company produces (or licenses) not only reproductions of his paintings, but also jewelry and sculpture, all the way up to gated communities marketed under the Kinkade brand.

He bills himself explicitly as a Christian artist, and many of his sculptures have overtly Christian themes. His licensed "collectible," Nativity Tree: Glory to The Newborn King Christmas Tree, available from Hawthorne Village, is a rather jumbled, electrically lit Christmas tree wrapped by a spiral footpath dotted with scenes from the nativity story, incorporating over 40 characters and playing the tune of "Silent Night." Another internally lit mass-produced sculpture, Faith Mountain (labelled oddly as "Religious Christian Home Decor"), also available from Hawthorne Village, is a cone-shaped "mountain" which looks more like another Christmas tree than most natural mountains, sporting a mix of glowing Middle-Eastern buildings and scenes from the Stations of the Cross (the advertising copy proclaims that "With each beautifully sculpted scene, you can almost feel Jesus' love, faith, and strength"). ${ }^{40}$ And there is the Noah's Ark figurine collection available from Hawthorne Village, a fat brown ship engraved with animal scenes and filled with removable pairs of animal figurines. There are many other Kinkade "collectibles" to choose from, such as the Thomas Kinkade "Light of Peace" Collectable Lighthouse music box available from Ardleigh Elliott (a replica of a gas lamp, internally lit, filled with a three-dimensional lighthouse scene, which plays "Somewhere Out There"), or the Thomas Kinkade Beauty in Flight "Garden of Prayer" Hummingbird, from the "Wall Decor Art

painting show, Painting with Morris. See Tanya Perez-Brennan, "Deltona Painter Takes to Airwaves: Like His TV Mentor Bob Ross, Morris Wiener Brings Art to PBS," Orlando Sentinel, Florida (Oct. 26, 2006).

33 The phrase is so characteristic that Bob Ross, Inc., offers a number of t-shirts festooned with the phrase, "Happy Trees," coupled with a picture of Bob Ross, usually working on a painting.

${ }^{34}$ Indeed, I am informed that Bob Ross's program, Joy of Painting, was a staple in the lounge of a ward in Building 40 of the Creedmoor Psychiatric Center in Queens, NYC, circa 2001. Thanks to Tim Noe, who was a MHTA (Mental Hygiene Therapist Assistant) there at the time.

${ }^{35}$ I owe the string of honorifics to Schroeder, "Aesthetics Awry," p. 87.

36 Orlean's "Art for Everybody" mentions a lithographic Kinkade reproduction, Julianne's Cottage, which sold for hundreds of dollars (US) initially but, having traded hands a number of times, fetches close to US $\$ 4,000$. She reports that a reproduction given highlights by Kinkade himself (a "Master Edition") can sell for US $\$ 34,000$. For a reproduction of a painting of a house, one could almost purchase a very modest home. Kinkade has come out with some do-it-yourself products aimed at children, but those products are very peripheral to his output and stylistically unusual.

${ }^{37}$ According to Schroeder's recent account, Kinkade's chain has 350 Signature Galleries. Schroeder, "Aesthetics Awry,” p. 90.

38 See Orlean, "Art for Everybody."

${ }^{39}$ If one observes reproductions of both paintings as the same time, it becomes evident that the flags in each of these two paintings are perfect copies of each other, right down to their particular pattern of ripples. It is true that not all of Kinkade's paintings are hyper-American: in a move not unlike Stephen King's writing novels under the name of Richard Bachman, Kinkade has painted under the pseudonym-or "brush name"-Robert Girrard, a fictional French painter who prefers impressionist-inspired rainy European street scenes and depictions of the sun-lit European countryside.

${ }^{40}$ In his essay on traditional kitsch, Ĉelebonović's remarks on the popularity of traditional kitsch include such internally lit sculptures: "We need only walk through the streets of Venice and pass by the useless kiosks offering plastic or metal San Marco campaniles and gondolas of all sizes lit by electric lanterns." "Notes on Traditional Kitsch," in Dorfles, Kitsch: The World of Bad Taste, p. 288. 
Collection," available from the Bradford Exchange, a bas-relief sculpture of a hummingbird with details from a Kinkade garden scene painting reproduced on its open wings. ${ }^{41}$

Both Bob Ross and Thomas Kinkade made successful businesses out of painting, but there is an important difference between the two (not merely that Thomas Kinkade has generated much more income). ${ }^{42}$ Bob Ross's The Joy of Painting, as I see it, is about combining self-reliance (its "do-it-yourself" aspect) and the creation of a personal area of retreat in one's home. Kinkade, on the other hand, though contributing to creating a domestic retreat, weds consumerism with Christianity and patriotism through a traditional kitsch (or Burkean beauty) that I will argue ultimately assists in hiding America's abuse of humanity. Kinkade's kind of traditional kitsch, I think, shows us a sort of dangerous kitsch common in the United States. There are certainly religious elements to Bob Ross's The Joy of Painting - he ends his broadcast with the words, "Happy painting, and God bless," for example — but The Joy of Painting is simply not aggressively Christian and patriotic in the way that Kinkade's output is. ${ }^{43}$

A second difference between Bob Ross and Thomas Kinkade is that Kinkade's product, when considered in its entire variety and totality, is potentially life-engulfing. The Kinkade brand extends not merely to reproduced paintings and "collectibles," but to almost everything one could have in one's home, including the home itself. One can make one's entire life, away from work and shopping, a "timeless" Kinkade "moment." For the person who consumes all of Kinkade, Kinkade can be all-consuming. One may perhaps debate whether the differences between the Bob Ross and Kinkade are ultimately quantitative or qualitative, but with Kinkade, it has to be admitted that the quantitative differences are so great that one has entered new territory.

\section{The Danger of Burkean Beauty: Political Kitsch $^{44}$}

Let us step back for a moment and return to the significance of Burke's conception of beauty. Burkean beauty can be understood as fostering a sort of common, decent kindness that humans need to share with one another and live within. However, the current US administration under George W. Bush keeps US citizens-classified as "unlawful combatants"- under indefinite solitary confinement without access to a lawyer, or abuses and tortures foreign detainees in Guantánamo, Cuba, or Abu Ghraib, Iraq. ${ }^{45}$ And an essential part of creating that world of isolation, torture, and abuse is to first remove from them all beauty, which means: all comfort, all social connection, all sanctuary. ${ }^{46}$ The fact that the United States is systematically eliminating beauty, in order to "soften up" real people for an even worse fate, is something many Americans would rather not think about.

I have argued above that some traditional kitsch can have a justifiable place as a part of creating a domestic space where the dweller feels protected and can find some sort of rejuvenation of healthy social feeling. But some forms of kitsch are not simply means for producing a domestic zone of safety; they function not merely to maintain beauty in the home but also to block one's knowledge of the destruction of beauty outside of one's home. Perhaps an example might help make that last assertion more intelligible.

One sculpture - or rather, figurine - is the avatar of the sort of kitsch-assisted veiling function that I have in mind. It is a small "collectible" approximately four inches tall distributed as part of the Hamilton Collection under the title Lord Bless This

\footnotetext{
${ }^{41}$ For Ĉelebonović, such functional mish-mashes are emblematic of much traditional kitsch. The caption for two of his essay's illustrations states that "The beer-mug-cum-tower and the tray with the pseudo-lace design are two examples of a type of kitsch which have remained unchanged for more than half a century." "Notes on Traditional Kitsch," p. 281. The Kinkade titles and copy were retrieved from the $<$ www.collectiblestoday.com> website. For more on the aesthetics of collecting, see Kevin Melchionne, "Collecting as an Art," Philosophy and Literature 23:1 (April 1999): 148-156.

42 According to Schroeder, "One in twenty American homes proudly displays a Kinkade art-based product; his sales reached \$131 million in 2001." Schroeder, "Aesthetics Awry," p. 90.

43 Schroeder writes that "Many [of Kinkade's paintings] are religious, in a light-handed way," but by this he simply means "no crucifixions here." Schroeder, "Aesthetics Awry," pp. 93-94. But this absence of crucifixions actually has more to do with the fact that Schroeder is discussing Kinkade's paintings, which, as he notes, are depopulated. As we have already seen, Kinkade's licensed "collectibles" do depict the Via Dolorosa, albeit by no means in any way approaching the treatment of the same theme by Mel Gibson's blood-soaked The Passion of the Christ (2004). Again, Gibson's gory spectacle would fit better under the class of entertainment and bear more kinship with Burke's sublime. For a wider contextual discussion of why people decorate their homes with depopulated landscapes, see David Halle, Inside Culture. ${ }^{44}$ My discussion here focuses primarily on political functions for Burkean beauty, not the Burkean sublime. For a perceptive and stimulating discussion of political functions for the Burkean sublime, see Cresap, "Sublime Politics." In the present article, I am using a somewhat streamlined version of Burke's concept of the beautiful, whereas Cresap's article, instead of passing over inconsistencies, combs Burke's theory for internal contradictions that might indicate hidden agendas or overlooked drawbacks to Burke's approach.

45 Out of many potential sources, a particularly striking account is given in the report by Human Rights Watch under the title "Torture in Iraq," The New York Review of Books 52:17 (November 3, 2005).

${ }^{46}$ Engendering the Burkean sublime is also taking place in such contexts (see e.g., Burke, Philosophical Enquiry, Part II, Sect. VI), but, as stated earlier, my focus here is Burkean beauty.
} 
Defender of Freedom. ${ }^{47}$ Judging from the photograph online, it appears that a fuller title is actually part of the figurine itself, written in tall blue letters across the front of its base: Lord Bless This Defender Of Freedom / And Keep Him Safe In Your Hands. The figurine itself, photographed in front of a deep blue background, presents a Caucasian soldier standing within a pair of monumental, transparent hands, as if cupped from behind by them, so that presumably - from the "God's-eye perspective"pine in them. The soldier wears desert camouflage and black boots; the Kevlar helmet strapped on his head is also in desert camouflage, and centered in its front are a pair of black ballistic goggles with a yellow lens. On his back he wears a green rucksack, the straps of which are visible from the front. The only element breaking the symmetry of the sculpture (other than an item on his belt, possibly a canteen or ammunition pouch) is a black military rifle (apparently an M-16), held flat against his body with both hands (the "ready" position), pointing down slightly to his left.

One crucial feature is required to grasp the full effect of the figurine, however: the soldier is infantilized. He is represented as a very young boy, with a large, round head (his body is less than three heads tall), large eyes, exaggerated eyelashes, tiny nose and mouth, short legs, large feet, and short, stubby fingers. Most of the details of the sculpture have been rounded and smoothened. The expression on his face does not suggest that he is defending anything. To the contrary: instead of appearing to be keeping lookout, his face presents us with a blank, wide-eyed stare. His mouth is curved into a gentle smile. His demeanor is more inviting than threatening. It seems to suggest he is waiting to be petted or offered a cookie.

The website copy explains to the prospective customer that [n]o matter where his mission takes him, he'll never be beyond the reach of God's protection. As the brave members of the U.S. military head out to defend our freedom, it's comforting to know that each one is sheltered in the loving hands of God. Keep this radiant tribute near as a brilliant reminder of all those who proudly serve our country. Meticulously crafted by hand, this limited-edition Hamilton Collection collectible figurine is filled with authentic details. Please hurry to order now.

This figurine is the iconographic epitome of what we might call "political kitsch": that traditional kitsch, that Burkean beauty, which serves the function of replacing not only American casualties and war-wounded but also those kidnapped, tortured, or killed in the United States' foreign "adventures." All the consequences of American militarism and empire-building disappear in a decontextualized religious veil of cuteness: a gun snuggled in sanctified cotton candy. The distance that has been travelled simply in religious terms can easily be seen by comparing this image of God's hands to that of the New Testament: there it is not an adorable, clean little boy, but instead a battered, bloody torture victim who cries to the heavens and says, "Father, into your hands I commend my spirit" (Luke 23:46). ${ }^{48}$

\section{Kinkade and Political Kitsch}

At heart here is the difference between a domestic function and a wider, political function for traditional kitsch. Traditional kitsch that takes on this wider political function is more obvious in the case of overtly political products, such as advertising campaigns and video spots for political candidates. ${ }^{49}$ Yet "merely" domestic decoration may also have a greater or lesser involvement in the world outside of the home. In the case of the Lord Bless This Defender of Freedom figurine, a miniature explicitly stated to

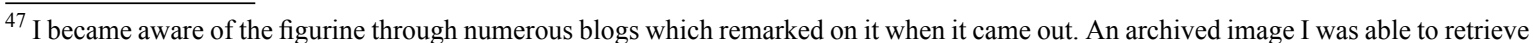
dated it to still be on sale on <www.collectiblestoday.com $>$ as of April, 2003, but according to that website, it is now completely sold out. To locate an image of it online, use a search engine to find web pages containing the collectible's item number (0912316001) or its short title, Lord Bless This Defender of Freedom.

${ }^{48}$ My discussion of political kitsch does not preclude a political use of the sublime — indeed, the two may be used in tandem-but my focus in this essay is the Burkean idea of beauty. Certainly Mel Gibson's The Passion of the Christ (something I would for the most part classify as a form of entertainment, insofar as it is clearly meant to excite, disturb, and upset the viewer through fear and pity) would be a possible candidate for a political use of the Burkean sublime. Cresap's "Sublime Politics" can again be recommended in this relation. For more on some of the numerous agendas which Gibson's film pursued (most of them political to a lesser or greater degree), see the articles by Margaret Mitchell et al. published under the collective title, "Perspectives on Mel Gibson's Passion" in Criterion 43:2 (Spring 2004): 20-27, and $37-38$.

${ }^{49}$ Here the exemplar would be the 1984 "Morning in America" television advertising campaign for Ronald Reagan, famous for its softfocus, sunlit images of an idyllic America: morning scenes, smiling citizens raising American flags, and young children's glowing faces. According to a recent piece by George Raine on the campaign, "The thinking was that positive and poetic would trump crass and demeaning." A possible component of the campaign's success, he claims, was the fact that "it was not what people expected political advertising to be-nasty and combative." Instead, according to Republican strategist Dan Schnur, Hal Riney (the principle writer for the ad campaign) "ha[d] the ability to cloak a strong message inside of a softer approach. ... Most political advertising hits viewers over the head, while his work ma[de] just as strong a point but in a less confrontational and a more soothing manner." George Raine, "Creating Reagan's Image: S.F. Ad Man Riney Helped Secure him a Second Term," San Francisco Chronicle (June 9, 2004).
} 
be of a "brave [member] of the U.S. military head[ing] out to defend our freedom," the connection is hard to deny.

But what about Thomas Kinkade? The Lord Bless This Defender of Freedom figurine presents merely the functional distillate of the Kinkade phenomenon. Though Kinkade's products (so far as I have seen) do not participate in infantilizing adult figures, his licensed "collectibles" do have a toy-like quality, and his brand, especially when considered in toto, carries out the function of the figurine to a much greater degree. As mentioned before, his entire brand engulfs almost all aspects of domestic life, up to and including the house itself. Kinkade's brand offers the hope of not merely decorating one's home with a canvas-textured print of a cozy Kinkade village which evokes a mythical bygone era of safety and Christian values, but the possibility of actually living in a cozy Kinkade village which evokes (or claims to evoke) a mythical bygone era of safety and Christian values. ${ }^{50}$ Given also that the present administration is cloaking its foreign policy in the rhetoric of a mythical bygone era of safety and Christian values, a rhetoric which also aggressively pursues the synthesis of consumerism with Christianity and patriotism, an administration that has made it all but impossible to photograph and disseminate photographs of the returning caskets from Iraq and Afghanistan, the functional kinship between Kinkade's product and the wider political landscape become easier to see. In Kinkade's world, it seems, the warm, glowing light which seems to soak into everything falls upon no caskets of America's fallen, illuminates no detainees who have suffered "extraordinary rendition," reveals no American pre-emptive strikes.

And what's wrong with that? Danto worries that one might precipitously write off the possibility of a place for beauty in art because of a concern with what he calls the artistic "sentimentalization of suffering," where "the use of beauty is perverse" because it "is not a consolation but a relish, a device for enhancing the appetite, for taking pleasure in the spectacle of suffering." He argues for a legitimate role for beauty in art when it functions as an elegy, or, in another example, when it creates a hedonistic

medieval garden - a garden of love - from whose precincts everything inconsistent with the atmosphere of beauty has been walled off. To be in the presence of a Matisse is to look into that garden and to be in the presence of - the embodiment of - the spirit of that garden: a fragment of the earthly paradise. But what precisely is wrong with creating a place of beauty in a bad world? Matisse certainly knew what the world is like. ${ }^{51}$

But what if the wider social function of the artwork is precisely to help prevent one from ever remembering - or possibly even becoming aware of - "what the world is like" in the first place? What if that function is to allow one to construct a religio-patriotic fantasy so that uncomfortable facts about one's national identity would not easily come to the fore? In such a case, one does not simply create a garden of repose away from the world, but seeks to forget that a world outside the garden even exists. The fundamental maneuver at play in this political kitsch is that Burkean beauty itself covers up the elimination elsewhere of desperately needed Burkean beauty and, simultaneously, the elimination of the compassion that Burkean beauty is also supposed to foster. Here political kitsch subverts the social function of Burkean beauty.

The proposition that Burkean beauty can actually undermine its own purpose may at first seem somewhat far-fetched. But pause to consider a parallel, and not unrelated, case: the philosophy of freedom. The political philosopher and social theorist Susan Buck-Morss opens her stunning essay, "Hegel and Haiti," with this remark:

By the eighteenth century, slavery had become the root metaphor of Western political philosophy, connoting everything that was evil about power relations. Freedom, its conceptual antithesis, was considered by enlightenment thinkers as the highest and universal political value. Yet this political metaphor began to take root at precisely the time that the economic practice of slavery - the systematic, highly sophisticated capitalist enslavement of non-Europeans as a labor force in the colonies - was increasing quantitatively and intensifying qualitatively to the point that by the mideighteenth century it came to underwrite the entire economic system of the West, paradoxically facilitating the global spread of the very Enlightenment ideals that were in such fundamental contradiction to it. ${ }^{52}$

She documents this fundamental contradiction in the national identity of four Western countries - the Netherlands, Britain, France, and the United States - a contradiction affecting not merely their national identities, but even the theories of their most

\footnotetext{
${ }^{50}$ According to Schroeder, that hope may not be fulfilled by the actual housing development. Schroeder, "Aesthetics Awry," pp. 93-95. See also Janelle Brown, "Ticky-Tacky Houses from the Painter of Light," Salon (March 13, 2002).

${ }^{51}$ Danto, The Abuse of Beauty, p. 114-115.

52 Susan Buck-Morss, "Hegel and Haiti," Critical Inquiry 26:4 (Summer 2000): 821-865.
} 
celebrated political philosophers, from Locke to Rousseau. $^{53}$

Lest one believe that these are hoary old examples from an irrelevant past, Buck-Morss also shows how these very same contradictions inform the academic output of entire disciplines right up to the present day, contradictions that rest on a systematic "scholarly blindness that ... silences the past." ${ }^{, 54}$ She clarifies:

If this paradox [of a philosophy of universal freedom which is able to gloss over a global system of slavery] did not seem to trouble the logical consciousness of contemporaries, it is perhaps more surprising that present-day writers, while fully cognizant of the facts, are still capable of constructing Western histories as coherent narratives of human freedom. The reasons do not need to be intentional. When national histories are conceived as self-contained, or when the separate aspects of history are treated in disciplinary isolation, counterevidence is pushed to the margins as irrelevant. $^{55}$

By this point, the connections to "political kitsch" should be clear: turning to the present context for political kitsch, we are faced with a fundamental contradiction. On the one hand, we see a fervent desire on the part of many Americans to believe their nation embodies a "coherent narrative of human freedom" that their President puts into these words: "From the day of our Founding, we have proclaimed that every man and woman on this earth has rights, and dignity, and matchless value, because they bear the image of the Maker of Heaven and earth., ${ }^{, 56}$ On the other hand, the executive branch of their own government is carrying out an indefinite extrajudicial confinement of its own citizens under a de facto waiver of habeas corpus, carrying out the kidnapping and "extraordinary rendition" of foreign citizens around the world, and carrying out the torture of randomly collected prisoners in Iraq, sometimes to the point of death - none of which, to put it mildly, speaks to any concern for their being made in "the image of the Maker of Heaven and earth."

As Buck-Morss points out, the elimination of uncomfortable counterevidence to the national narrative of freedom need not be intentional; it will happen almost of its own accord. But intentional or not, it would certainly be eased by an iconography according to which American soldiers are child-like "defenders of freedom," the United States a country whose flag is simply America's Pride or The Light of Freedom, and whose homes always throw a warm, "timeless" light over pristine village snowbanks. In the case of Thomas Kinkade, the ideal in question is that - for those who can afford it — one can disappear completely into an a-historical "religious Christian" brand, a commercially licensed gated community. ${ }^{57}$

When considering Thomas Kinkade's Christian fantasies or the unsettling Lord Bless This Defender of Freedom "collectibles," one may begin to have some sympathy for Richard Egenter's diatribes against the satanic evil of kitsch. What this political kitsch - the dangerous potential within traditional kitsch - involves, however, is not direct evil, but an indirect evil, a sin of omission: the oblivious masking of true evil elsewhere. Hegel once complained that the citizens of Leipzig decorated their breaking wheel with flowers. ${ }^{58}$ In our case, the flower blocks the view of torture altogether.

\section{References}

Broch, Hermann. Schriften zur Literatur 2: Theorie. Ed. Paul Michael Lützeler. Frankfurt am Main: Suhrkamp Verlag, 1975.

Brown, Curtis. Star-Spangled Kitsch: An Astounding and Tastelessly Illustrated Exploration of the Bawdy, Gaudy, Shoddy Mass-Art Culture in This Great Land of Ours. New York: Universe Books, 1975.

Brown, Janelle. "Ticky-Tacky Houses from the Painter of Light ${ }^{\mathrm{TM}}$." Salon (March 13, 2002).

$\mathrm{URL}=<$ http://dir.salon.com/story/mwt/style/2002/03/18/kinkade_village $>$

Buck-Morss, Susan. "Hegel and Haiti." Critical Inquiry 26:4 (Summer 2000): 821-865.

Burke, Edmund. A Philosophical Enquiry Into the Sublime and the Beautiful [1757/1759]. New York: Penguin Books, 1998/revised 2004.

Ĉelebonović, Aleksa. "Notes on Traditional Kitsch.” In Gillo Dorfles, Kitsch, pp. 280-289.

Cresap, Steven. "Sublime Politics: On the Uses of an Aesthetics of Terror." Clio 19:2 (Winter 1990): 111-125.

\footnotetext{
53 Buck-Morss, "Hegel and Haiti," pp. 821-832.

${ }^{54}$ Buck-Morss, "Hegel and Haiti," passim. Buck-Morss credits Michel-Rolph Trouillot, Silencing the Past: Power and the Production of History (Boston: Beacon Press, 1995), for this formulation at p. 834, n. 39.

${ }_{55}$ Buck-Morss, "Hegel and Haiti," p. 822, my emphasis.

${ }^{56}$ George W. Bush's second inaugural address (January 20, 2005).

57 The "timelessness" so often referred to in the copy accompanying Kinkade's products suggests a number of things, such as high-end value, but in the present context also a desire to run away from modernity and from history itself.

${ }^{58}$ Georg Wilhelm Friedrich Hegel, "Who Thinks Abstractly?" translated by Walter Kaufmann, in Hegel: Texts and Commentary (Garden City, NY: Anchor Books, 1966), pp. 113-118.
} 
Danto, Arthur C. The Transfiguration of the Commonplace: A Philosophy of Art. Cambridge: Harvard University Press, 1981.

. The Abuse of Beauty: Aesthetics and the Concept of Art. The Paul Carus Lectures, 21. Chicago: Open Court, 2003.

Dorfles, Gillo. Kitsch: The World of Bad Taste. New York: Bell Publishing, 1969.

Egenter, Richard. The Desecration of Christ. Ed. Nicolete Gray, trans. Edward Quinn. Chicago: Franciscan Herald Press, 1967. Translation of Kitsch und Christenleben. Buch- und Kunstverlag Abtei Ettal, 1950.

Emmer, C. E. "Kitsch Against Modernity." Art Criticism 13:1 (1998): 53-80.

. Review of Stallabrass, High Art Lite. Metapsychology 7:20 (2003).

$\mathrm{URL}=<\mathrm{http}: / /$ mentalhelp.net/books/books.php?type=de\&id=1706>.

Greenberg, Clement. "Avant-Garde and Kitsch.” In Art and Culture: Critical Essays. Boston: Beacon Press, 1961, pp. 3-21.

Halle, David. Inside Culture: Art and Class in the American Home. Chicago: University of Chicago Press, 1986.

and Elisabeth Tiso. "The Structure of Contemporary Art: The Case of Chelsea in New York City." Paper presented at the International Symposium on the Arts in Society, February 23-25, 2007 at the Tisch School of the Arts at New York University, NYC.

Hegel, Georg Wilhelm Friedrich. "Who Thinks Abstractly?" Translated by Walter Kaufmann. In Hegel: Texts and Commentary. Garden City, NY: Anchor Books, 1966, pp. 113-118.

Hemingway, Wayne. Just Above the Mantelpiece: Mass-Market Masterpieces. London: Booth-Clibborn Editions, Ltd., 2000.

Human Rights Watch. “Torture in Iraq.” The New York Review of Books 52:17 (November 3, 2005). $\mathrm{URL}=<\mathrm{http}: / /$ www.nybooks.com/articles/18414>.

Melchionne, Kevin. "Collecting as an Art." Philosophy and Literature 23:1 (April 1999): 148-156.

Mitchell, Margaret, with Robert Franklin, Father John Pawlikowski and Rabbi David Sandmel, and Seth Sanders. "Perspectives on Mel Gibson's Passion." In Criterion 43:2 (Spring 2004): 20-27 and 37-38.

Negrin, Llewellyn. "The Contradictory Nature of our Relation to Beauty in Contemporary Culture." The International Journal of The Arts in Society 1:3 (2007): 135-140.

Orlean, Susan. "Art for Everybody: Thomas Kinkade, America's Most Profitable Artist." The New Yorker (October 15, 2001): 124-146.

Perez-Brennan, Tanya. "Deltona Painter Takes to Airwaves: Like His TV Mentor Bob Ross, Morris Wiener Brings Art to PBS.” Orlando Sentinel [Florida] (Oct. 26, 2006).

Raine, George. “Creating Reagan's Image: S.F. Ad Man Riney Helped Secure him a Second Term.” San Francisco Chronicle (June 9, 2004).

Schmidt, Hartwig. Grausamkeit und andere Lüste: Ethische Essays. Berlin: Berliner Debatte Wissenschaftsverlag, 1998.

Schroeder, Jonathan E. "Aesthetics Awry: The Painter of Light and the Commodification of Artistic Values." Consumption, Markets and Culture 9:2 (June 2006): 87-99.

Sontag, Susan. "Notes on Camp." In Against Interpretation: And Other Essays [1966]. New York: Picador/Farrar, Strauss and Giroux, 2001.

Stallabrass, Julian. High Art Lite: British Art in the 1990s. New York: Verso Books, 1999. . Art Incorporated: The Story of Contemporary Art. Oxford: Oxford University Press, 2004

Trouillot, Michel-Rolph. Silencing the Past: Power and the Production of History. Boston: Beacon Press, 1995.

Ward, Peter. Kitsch in Sync: A Consumer's Guide to Bad Taste. London: Plexus, 1991.

White, Stuart. "Social Minimum." The Stanford Encyclopedia of Philosophy (Winter 2004 Edition). Ed. Edward N. Zalta. $\mathrm{URL}=<$ http://plato.stanford.edu/archives/win2004/entries/social-minimum/>.

\section{About the Author}

\section{Dr. C. E. Emmer}

My doctoral work explored the significance of formalism and the senses in Kant's mature aesthetics. Currently, my work focuses on 18th-century German aesthetics (particularly Kant and Herder) and additionally the question of "kitsch," though I am also interested in Latin American and especially Brazilian contributions to these topics. I am presently completing numerous translations from the German and writing about weaknesses in Kant's theory of poetic beauty. 
THE INTERNATIONAL JOURNAL OF THE ARTS IN SOCIETY

\section{EDITORS}

Mary Kalantzis, University of Illinois, Urbana-Champaign, USA.

Bill Cope, University of Illinois, Urbana-Champaign, USA.

\section{EDITORIAL ADVISORY BOARD}

Robyn Archer, Performer/Director. Former Artistic Director, European Capital of Culture 2008, Liverpool, UK.

Tressa Berman, Executive Director, BorderZone Arts, Inc., San Francisco, USA; Visiting Research Faculty, University of Technology, Sydney (UTS), Australia.

Judy Chicago, Artist and Author, New Mexico, USA.

James Early, Director of Cultural Heritage Policy, Smithsonian Institution, Center for Folklife and Cultural Heritage, and Acting-Interim Director, Anacostia Museum Center for African American History, USA.

Mehdi Faridzadeh, President, International Society for Iranian Culture (ISIC), New York and Tehran, Iran.

Jennifer Herd, Artist, Curator, and Founding Faculty, Bachelor of Visual Arts in Contemporary Indigenous Arts, Queensland College of Art, Griffith University, Brisbane, Australia.

Fred Ho, Composer, Writer, Producer. New York, USA.

Andrew Jacubowicz, Faculty of Humanities, University of Technology, Sydney, Australia.

Gerald McMaster, Curator of Canadian Art, Toronto, Art Gallery of Ontario, Canada.

Mario Minichiello, Academic Director and Chair, Loughborough University School of Art and Design, UK.

Fred Myers, Professor and Chair, Department of Anthropology, New York University, USA.

Darcy Nicholas, Contemporary Maori Artist. General Manager, Porirua City Council, Pataka Museum of Arts and Cultures, Aotearoa/New Zealand.

Arthur Sabatini, Associate Professor of Performance Studies, Arizona State University, USA.

Cima Sedigh, President, Global Education and Health Alliance, Faculty of Education, Sacred Heart University in Fairfield, Connecticut, USA.

Peter Sellars, Opera Director, World Cultures Program, University of California, Los Angeles, USA. Judy Spokes, Director, Cultural Development Network, Australia.

Tonel (Antonio Eligio), Artist, Art Critic, University of British Columbia, Canada, and Havana, Cuba.

Marianne Wagner-Simon, Independent Curator and Producer, Berlin, Germany.

Please visit the Journal website at http://www.Arts-Journal.com for further information:

- ABOUT the Journal including Scope and Concerns, Editors, Advisory Board, Associate Editors and Journal Profile

- FOR AUTHORS including Publishing Policy, Submission Guidelines, Peer Review Process and Publishing Agreement

\section{SUBSCRIPTIONS}

The Journal offers individual and institutional subscriptions. For further information please visit http://ija.cgpublisher.com/subscriptions.html Inquiries can be directed to subscriptions@commongroundpublishing.com

INQUIRIES

Email: cg-support@,commongroundpublishing.com 